\title{
An Intimate Knowledge of 'Maori and Mutton-Bird': Big Nana's Story
}

\section{MICHAEL J. STEVENS}

The institution of mutton-birding is as old as the hill, and from time immemorial it has been the right of the Murihiku natives to gather [tìt $1 /$ muttonbirds]...it is one of the few natural advantages yet entirely in their hands, and they strongly resent the intrusion of pakehas into it.

$$
\text { Nga-Ti-Ngaro, } 1902 .^{1}
$$

Pakehas, married to Natives so privileged, also have a legal right to participate in these [tītī harvesting] activities.

L. E. Richdale, $1946 .^{2}$

'The young of the [tītī] are taken annually for food by those Maoris who hold ancestral rights', so wrote Lance Richdale in 1946. Richdale, a prodigious avifauna researcher affiliated with the Department of Zoology at the University of Otago, thus introduced muttonbirding in his book Maori and Mutton-Bird. ${ }^{3}$ Conducted on nearly three-dozen islands south of mainland New Zealand, this seasonal activity centred and centres - on the harvesting, processing, preservation, transportation and trade of fledgling tītī by southern Māori families from the Kāi Tahu tribe. ${ }^{4}$ True, Māori kingroups throughout New Zealand harvested several species of muttonbird before and after European settlement, but barring a few notable exceptions, this has ceased (due to tribal land-loss and habitat destruction including the localized extinction of bird species following the introduction of rats and mustelids). However, the Foveaux Strait region was and remains renowned for the large number of juvenile tìtì available there. It is the only part of New Zealand that plays host to anything approaching the harvest of short-tailed shearwaters (yolla) in Bass Strait by indigenous Tasmanian muttonbirders. ${ }^{5}$

Preserved tìtī were an important winter food source in pre-European New Zealand and their value was actually consolidated in the south during the imperial encounter, which we might date as the period 1792 to 1848 . Although subsequent British colonization rendered $90 \%$ of Kāi Tahu virtually or absolutely landless by the 1890s, the so-called Tìtī Islands were exclusively reserved for those genealogically entitled to them, and their descendants, in perpetuity. ${ }^{6}$ Accordingly, the importance of muttonbirding was consolidated during the colonial encounter too. Throughout the late nineteenth and early twentieth centuries the harvest acted as a partial bulwark against the tyranny of poverty, and as a social bonding agent that helped maintain a sense of tribal polity in the face of widespread intergenerational interracial marriage and government commitment to an idea of racial amalgamation. ${ }^{7}$

As foreshadowed above, the ongoing significance of muttonbirding in the colonial encounter was underwritten by its exclusivity - the islands have always been in Māori hands - a 'space to be [ourselves]'. ${ }^{8}$ However, this exclusivity was not absolute: legally married spouses of those with rights in one or more of the Titi Islands could also share in the risks and rewards of muttonbirding. ${ }^{9}$ This essay profiles one such person, a short and stout white (Pākehā) woman who twice married Kāi Tahu men. Her name was Frances Mercy Haberfield (née Bailey, formerly Spencer). She was my great-great-grandmother. Fan, as her friends called her, was 
known to many of her grandchildren (mokopuna) as Big Nana. That is what I know her as and that is how I refer to her throughout this essay.

Big Nana's story is significant because she played a pivotal role in the intergenerational transmission of a detailed set of Māori material traditions and associated environmental knowledge, both increasingly valued in the present day, that would otherwise have virtually ceased to exist. That she was a working-class Pākehā woman who married into a Kāi Tahu family (whānau) further situates her story as important, for it highlights the little known history of white New Zealand women who married 'out'. ${ }^{10}$ Moving beyond a history of race and intimacy that focuses upon sexual encounters in theatres of early contact, this essay is concerned with the longterm effects of such intimacy. Drawing upon family photos, practices and values, and rich family anecdotes - many anchored and retold in specific locations - Big Nana's story helps to shed light on the complex contours of race and intimacy in southern New Zealand during the twentieth century.

\section{Big Nana}

Frances Mercy Bailey was born in Invercargill, Southland, in 1885. She was the fourth of eleven children born to Frederick Percy Bailey (1859-1942) and his wife Elizabeth (Bessie) Cunnack Toman (1858-1928). Frederick and Bessie were both from Penzance, southern Cornwall, but immigrated to southern New Zealand in 1880. After an 87-day voyage that began at Gravesend and ended at Port Chalmers, Otago, the newlyweds planned on establishing themselves in Dunedin. ${ }^{11}$ However, they were met with the unfortunate news that their only point of contact there, a maternal uncle of Bessie's, had died while they were at sea. ${ }^{12}$

Contagious diseases and premature death, including high rates of infant mortality, were constants in the lives of both the colonized and the colonizers in the nineteenth-century world, albeit unequal ones. Like other virgin soil populations, Māori suffered disproportionately compared to Pākehā, especially with respect to the likes of tuberculosis. The idea of 'the dying Māori', a point of widespread discussion by the late nineteenth century, was not simply a semantic device. ${ }^{13}$ Good health was a precarious thing for Pākehā too. The family that Big Nana was born into, and those that she married into and created, illustrate this. Frederick's mother, for instance, died when he was a baby and his father, a master baker, died when Frederick was 14. This helps to explain why Frederick went to sea when he was $15 .{ }^{14}$ That in turn, I think, helps to explain why he and Bessie gravitated to port-settings, and thus to particular types of work in colonial Otago and Southland. ${ }^{15}$ Between 1882 and 1884 the couple lived in the western Southland town of Riverton where Frederick worked at the town's port, by then in an irreversible state of decline. ${ }^{16}$ In 1898 , after more than a decade in Invercargill, the family shifted finally to Bluff, Southland's sole deepwater port, where Frederick worked as a seaman and later a 'wharfie'. ${ }^{17}$

Married life was not easy for Frederick and Bessie. The latter's family, moderately wealthy Anglicans, never fully accepted Frederick, a Wesleyan from a much less well off family, which perhaps explains the couple's decision to emigrate to New Zealand. Alas, life in the colony was also difficult. The dust had settled on southern New Zealand's gold rush and a long depression bit deep from 1878 until 1895: commodity prices (including for wool, the backbone of the young nation's economy) plummeted; urban unemployment was high and labour conditions were poor. Working-class families struggled to make ends meet. Indeed, in 1891, Frederick, recently self-employed as a firewood cutter and then carter, went bankrupt. ${ }^{18}$ 


\section{Big Nana and George}

In 1904 Frances Mercy Bailey (Big Nana) married George Greig Spencer; he was 21 and she was $18 .{ }^{19}$ George was a son of William Spencer (1844-1938) and his wife Louisa Te Memeke Coupar (1846-1930). ${ }^{20}$ William's father was James Spencer, a sealer, whaler and trader, and Bluff's proverbial founding father. William's mother was Meri Te Kauri, of Kāi Tahu descent. Conducted at Waikouaiti (present day Karitane) by Rev. James Watkin, southern New Zealand's first foreign resident missionary, Meri and James's wedding in 1841 was the first Christian marriage in Otago-Southland. ${ }^{21}$ William's wife, Louisa, was born at The Neck, on Stewart Island (Rakiura). She was one of 12 children of Stewart Coupar, originally from Dundee, Scotland, and Te Mahana, a Kāi Tahu woman. ${ }^{22}$ Big Nana's marriage to George therefore connected her to large and prominent Bluff based Kāi Tahu families, and brought her into the ambit of tribal affairs in the south more generally.

Interracial cohabitation and marriage was a settled practice in and around Foveaux Strait for almost 50 years before systematic colonization proceeded. As Damon Salesa reminds us, colonialism in New Zealand claimed jurisdiction over, 'but did not inaugurate, relations between indigenous societies and outsiders' ${ }^{23}$ In one sense, therefore, Big Nana and George's marriage was simply the continuation of a well-established pattern. Yet I am not suggesting that interracial marriage was unproblematic or straightforward in colonial Otago and Southland - a sort of racially exceptional province in the supposedly racially exceptional nation, as generations of New Zealanders and New Zealand scholars saw, or still see, their country. ${ }^{24}$ The reality is that by the 1900 s, colonial society in the south could and did sustain itself with little or no interaction with Kāi Tahu, on whom early settlers had relied on for food, lodging, and environmental knowledge. And yet, many Kāi Tahu continued to marry Pākehā spouses over this period. How do we reconcile these two things?

First, class and locale were often more critical factors than race, especially in the pockets of colonial Otago where 'crew culture' persisted. ${ }^{25}$ Bluff, which started out as a shore-whaling base - an archetypal middle ground - was one such place. ${ }^{26}$ During its colonial development the port continued to draw in Kāi Tahu people from right across the tribe's territory (takiwā). People were attracted by the demand for seamen, wharfies, fishermen, boat-builders, and similar maritime related work. ${ }^{27}$ Many of the Pākehā who lived in coastal settings like Bluff, and engaged in the same sources of employment and enjoyment, frequently had more in common with their Kāi Tahu neighbours than with inland communities of agriculturally centred Pākehā, or 'respectable Anglo-Celtic colonists', as Tony Ballantyne describes them. ${ }^{28}$ Second, by the turn of the twentieth century, many Kāi Tahu were culturally (and often physically) more like Pākehā than Māori anyway. In other words, from a Pākehā perspective, Kāi Tahu were much less 'other' and much more 'alike'. As the social anthropologist John Harré put it in the 1960s, 'the formation of [Māori-Pākehā] relationships is accelerated when the cultural differences are minimized' ${ }^{29}$

Even so, Big Nana and George's relationship was significant in that she, rather than he, was white. The prevailing pattern in Foveaux Strait, like other colonial contexts, was predominantly the other way around, and variously imagined as a strategic tactic of conquest or a key tool in civilizing redeemable heathens. ${ }^{30}$ The idea of native men 'taking' white women did not meet with the same level of acceptance in 
European thought. We can surely see such abhorrence in Shakespeare's Othello where the duplicitous Iago attempts to upset Brabantio by informing him that his daughter Desdemona was having premarital sex with Othello, a Moor: 'an old black $\mathrm{ram} /$ Is tupping your white ewe. ${ }^{31}$ As the reproducers of white children, white women carried the 'hopes, achievements, and character of the race', hence the anxieties attached to their sexuality. ${ }^{32}$

Referring to colonial era Kāi Tahu men, Angela Wanhalla notes that 'marriage to a white woman was unusual'. ${ }^{33}$ And yet, missionaries generally believed in the possibility and desirability of this type of interracial marriage in New Zealand. The Rev. J.F.H. Wohlers, for instance, who married Big Nana's second set of in-laws to one another, and baptised her second husband, 'had good hope that [southern Māori] would live, not as a separate race, but mixed up with the European settlers.' Indeed, by this time, 1870, he noted that, the 'half-castes and those of mixed blood, already exceed the pure Maoris'. ${ }^{34}$ The Rev. James Buller echoed these sentiments in an 1873 lecture where he denied that Māori were dying out. 'There will always be Maoris for generations,' he wrote, however '[t]hey will not always be a distinct race, nor is it to be desired.' He saw 'no reason why hereafter there may not be a blending of the races by intermarriage.' Significantly, Buller directly addressed the question of Māori men marrying white women and concluded that:

when the young Maori lad of the present time shall develop into the polished Māori gentleman of a future day - do you suppose that the fairest of England's daughters will then refuse to grace with her charms the palatial residence of a Māori aristocracy?

The same newspaper that published Buller's lecture also carried a rebuttal from 'A Noble Digger'. This person took Buller to task for his positive view of Māori and highlighted that 'after forty years of missionary teaching, they have not given up the disgusting, obscene suggestiveness of the war-dance'. It was thus hoped that intermarriage 'may long be confined to its present narrow scale' for 'it is certainly no part of the "mission" of the white race to miscegenate the Maoris into the condition of polished gentlemen'. However, if anyone believed so:

and has sisters or daughters to devote to his idea, he is welcome to try the experiment; but I, for one, would sooner see any female relative in the grave, than sharing the residence (however palatial) or the attentions (however polished) of any Maori, even though he might be removed by three generations from the cannibalism of his ancestors. ${ }^{35}$

Unsurprisingly, marriages of Māori males to Pākehā females were newsworthy items. In 1877, for instance, several New Zealand newspapers carried a story entitled 'Romantic Marriage of a European Woman with a Māori'. This article explained that the marriage of European men with Māori women is 'so frequent, that the announcement of such an event would not be likely to cause much remark'. However, the marriage 'of an intelligent fairly educated European woman ... with a Maori, is an event which does not often occur, and which consequently demands from us such exceptional notice as would be given in England to 'a marriage in high life'. In any event, its author hoped that the union under discussion, between Sydney Taiwhanga and Sarah Moran, would 'enjoy a happy and contented life, and this instance of miscegenation in New Zealand will prove beneficial to both races'. ${ }^{36}$ 
In 1880, five years before Big Nana was born, a similar instance of miscegenation in New Zealand proved to be anything but beneficial. Susan Snoswell, a Pākehā from Lyttelton who had married Wi Wharepa ('a well-to-do Native') of Chatham Island, was brutally bashed to death by her husband. ${ }^{37}$ According to him, his wife was 'a bad woman, and an adultress [sic] both with Maoris and Europeans'. ${ }^{38}$ Commenting on the case, a correspondent to the press wrote that:

The idea of a white woman marrying a Maori was looked upon, even in these isolated regions, with disgust; everyone could forsee [sic] that her life would be miserable and wretched in the extreme, and that she would put herself out of all social intercourse with her own countrywomen, but the sad and dreadful fate that has been hers should prove a warning to all white women who should contemplate such a mis-alliance for a moment. ${ }^{39}$

Inevitably, all white women did not heed the 'warning'. Even so, an 1892 newspaper article headed 'Intermarriages with the Natives', could state that ' $[\mathrm{t}]$ here are extremely few cases of the union of Maori males with European females, which have come under observation, and the parents have not always been good specimens, more particularly in the case of the female'. ${ }^{40}$

The foregoing suggests that many Pākehā would have looked down on Big Nana and made assumptions about her station, intelligence and worth. We know very little about what Big Nana and George themselves thought of each other's racial background. Nor do we know what their respective families thought of their union. Questions can be asked about the nature, and the limits, of the aforementioned crew culture (maritime-centred, usually multicultural, lifeways) in Bluff at this point in time. It would be naïve to think that racial discourse was absent from it: 'Sex across the colour line always represents more than just sex'. ${ }^{41}$ However, in this case at least, we simply do not know what this particular folk understanding looked like and what terms it employed, much less what they were taken to mean. ${ }^{42}$ As Damon Salesa suggests, there is a history of race from below, but retrieving it is no easy task. ${ }^{43}$

In any event it seems clear that a range of interracial intimacies were regular and acceptable in Bluff in the first half of the twentieth century that were not regular or acceptable in other parts of contemporary New Zealand, where there was often 'intense fear and anxiety' vis-à-vis interactions between Pākehā women and Māori men. ${ }^{44}$ At the same time, and despite Bluff's apparent 'spectrum of toleration', we know that the union of a Pākehā woman and a Kāi Tahu man was still an uncommon occurrence there in the early twentieth century. ${ }^{45}$ In 1920 , for instance, the noted ethnographer Herries Beattie, who spent time in and around Bluff, commented, that:

In years past white men used to marry Maori women but the collector came across two or three cases where Maori men had married white women. The latter seemed contented and no doubt had done better for themselves than they would have done with lots of Europeans. ${ }^{46}$

George's father, William Spencer, was one of Beattie's key informants. ${ }^{47}$ It is possible, indeed likely, that one of the women that Beattie referred to was Big Nana.

George worked as a 'seagull' - a casual employee - on the Bluff wharf where much of his time would have been spent loading English-owned Indian-crewed ships with Southland-raised frozen mutton destined for London's East End. Big Nana, by now mother to a blue-eyed baby boy, Stewart Bruce, born in 1905, is described by Georgina Ellis as having been 'welcomed into the elder Spencers' household as 
another daughter'; this was literally true as the couple lived with his parents. ${ }^{48}$ Some might be tempted to read this as possible evidence of her parents' disapproval of her choice of husband, possibly on the basis of his racial background. However, there is no family tradition of such a thing. Moreover, when Big Nana later remarried, again to a Kāi Tahu man (my great-great-grandfather), that marriage took place in her parents' home - hardly a sign of deep dissatisfaction. Perhaps Big Nana and George lived with his parents simply because they had a bigger house, or had less people under its roof, and therefore more spare room than her parents? Which is to suggest that we should not overlook prosaic explanations for events in nonetheless racialized historical settings. Nor should we should rush to racialize motivations and decisions where the evidentiary base for doing so is limited or non-existent.

According to their granddaughter, my relative (whanauka) Georgina Ellis, Big Nana and George were 'friends since school'. Those simple words, like Georgina's further statement that 'their marriage was a natural outcome of mutual interests, picnics and dances', speak volumes. In Big Nana's own words, she had loved George since schooldays. ${ }^{49}$ These words remind us that intimacy means more than simply conjugal relations. Big Nana, like other Pākehā children from Bluff, shared classrooms and playfields, streets and shops, and boats and beaches, with non-Pākehā children. This was not the result of state directed 'pepper-potting', but rather Bluff's origins as a multi-ethnic shore-whaling base, and its role as a key site of Kāi Tahu 'holding-on'. ${ }^{50}$ Thus, in 2006, 43\% of Bluff residents self-identified as Māori, compared with $11.8 \%$ for the Southland region as a whole and $15 \%$ for all New Zealand. ${ }^{51}$ Consequently, Bluff was a place where Pākehā children also addressed elder Kāi Tahu men as Pōua, the Kāi Tahu word for grandfather. ${ }^{52}$ In contrast to the 'noticeable invisibility' of Māori inhabitants, as Beattie put it, in large parts of colonial Otago and Southland, Bluff was one of the key places 'that sheltered the Natives' and enabled them to keep 'close together [which] preserved their racial identity. ${ }^{53}$

Big Nana and George falling in love and getting married was an outcome of them growing up in the same small town. This suggests to me that in other parts of nineteenth and twentieth-century New Zealand, and in other settler colonies, where descendants of natives and descendants of newcomers were not physically proximate to one another, we might expect to find lower rates of interracial marriage and, I further assume, a lower a tolerance for it. In his research on interracial dating in 1960s Auckland social anthropologist John Harré commented that the 'initial reaction by a Pakeha to the possibility of a close relationship with a Maori is often associated with [an] unfavourable stereotype. This reaction is strongest in situations where the social distance is least.' However, he then wrote that '[o]ne of the most significant features of race relations in New Zealand is the rapidity and frequency with which the stereotype is broken down when events force a close association'. ${ }^{54}$

Living with her in-laws, Big Nana was introduced to a range of specifically Māori intimacies. Chief amongst these were values and practices that structured the harvesting, processing, exchange and consumption of wild foods (mahika kai). When Stewart was born, for instance, the family was instructed by medical authorities that he would not survive. In response he was nursed and fed livers from blue-cod, southern New Zealand's preeminent fish, and he survived. Another mahika kai that Big Nana was exposed to but did not enjoy were 'sea-tulips' (kaio). However, when Stewart was about 18 months old she asked for them, a request which prompted William to exclaim 'Hello, a jack-in-the-box!' ${ }^{55} \mathrm{He}$ thus correctly interpreted her 
craving as a sign (tohu) of her being pregnant. Big Nana's ultimate dislike of kaio contrasts strongly with her involvement in the south's most famous mahika kai muttonbirding, which is still a defining activity for southern Kāi Tahu, including many of Big Nana's own descendants.

\section{Te Manu Tītī - Horomamae}

Muttonbirding was a 'seasonal cornerstone' of William Spencer's working life. This owed much to both his Māori and Pākehā lineage: he variously worked as a whaler, seaman, and sawyer. These were highly gendered jobs and he was a 'man's man': some of his mokopuna recall him digging out one of his back teeth with a fork, which he nearly bent in the process. ${ }^{56}$ Muttonbirding, which Big Nana first participated in with her husband George and her in-laws on Te Poho o Horomamae, one of the Tìtī Islands, also became so much a part of her life that many of her descendants cannot separate their understanding of it from her, nor their understanding of her from it. This is especially because Big Nana became very proficient in many of the traditional methods associated with the harvest, including the traditional kelp-bags (he mahi pōhā) used to store and transport preserved tītì. As with the final production of pōhā on the Tìtī Islands, the mainland preparation of their constituent parts was communal work, almost always with multigenerational participants. William, in particular, as a fellow lefthander, taught Big Nana how to cut and prepare New Zealand flax (harakeke) and weave it into baskets in preparation for the season. ${ }^{57}$ Likewise, Big Nana learnt how to cut, shape and cure bull-kelp (rimurapa). The latter activity was a common feature of Kāi Tahu households and communities in southern New Zealand up until about the 1950s. As Beattie noted in 1920, '[f]or weeks before the [muttonbirding] season you can pick out the Maori residences at the southern ports by the line of kelp bladders in the yard. ${ }^{58}$

William Spencer is remembered as being 'unfailingly kind and considerate', however, he was not a patient man - '[s]tories of his temper are legendary.' With clenched fists and a sheath knife in his teeth he once chased a young boy who had unintentionally damaged kelp being collected for pōhā. ${ }^{59}$ William was a hard taskmaster and had exacting standards, especially when it came muttonbirding (this seemingly rubbed off on Big Nana, of whom the same is now said). Despite the obvious affection that William and Louisa had for their family and friends, living with him cannot have been easy. This is especially true in the context of a Tìtì Island where confined and basic lodgings, long hours of work, and broken sleep, tend to amplify the best and worst in people. If William considered that Big Nana and her sister-inlaw had been sitting too long having lunch, he would upend the table. Once, after Big Nana had prepared a large plum pudding solely for William, as she did every Sunday, he 'crunched on a small piece of grit, then a twig, from one of the sultanas. He threw it out the window, yelling 'This pudding is full of back-logs and boulders!!' 60

In August 1906, when Big Nana was three months pregnant with her second child, George, aged 24, died from tuberculosis and rheumatic fever. Six months later Big Nana gave birth to another boy, who was named George Greig after his father. She continued to live with her in-laws for the next three years.

\section{Big Nana and Pōua}

Through her brother-in-law Tom Spencer, Big Nana met William Isaac Haberfield (1874-1936), a widower who had recently lost his wife, adopted son, and sister-in-law in a tragic fire at Port Chalmers. The Spencers encouraged Big Nana to marry 
William Haberfield, known as Bill, but who I refer to as Pōua. A grandson of William Isaac Haberfield (1815-1906) a shore-whaler from Bristol who landed in Otago in 1836 and remained there, mostly at Moeraki, until his death, and Meriana Teitei (1810-1852), a well connected Kāi Tahu woman, Bill was born to John Kerle Haberfield (1845-1902) who was raised in Moeraki, and his wife Elizabeth (Noki) Honor (1839-1914), who was born on Whenua Hou (Codfish Island). The latter was the site of one of New Zealand's earliest interracial communities. John and Noki were married at Ruapuke Island in 1870 by the Rev. J.F.H. Wohlers, who inaugurated a mission there in 1844 under the very distant aegis of the North German Mission Society.

Big Nana and Pōua were married at Bluff in 1910. Pōua raised the two Spencer boys as his own, and he and Big Nana went on to have three children together. Their first child, a girl named Caroline Mouru (1911-1999), is my great-grandmother, known to me as Nana P. ${ }^{61}$ The other two were Koa Gladys (1916-2009) and John Kerle Tipaho (Boy) (1919-1945). In addition, they customarily adopted (whangai'd) two Kāi Tahu kin, a brother and sister, Buku and Taura Hemara, from Colac Bay. They also variously cared for Pōua's mother, Noki, his spinster sister Elizabeth (Lulla) Haberfield, and his nephew Carroll (Carl) Haberfield (1895-1987). ${ }^{62}$ In 1932 my grandfather, Nicholas Graham (Tiny) Metzger, was added to the mix after Nana P married Nicholas James (The Fox) Metzger (1909-1967), a grandson of a prominent Polish-German family that settled in Bluff in the late nineteenth century. ${ }^{63}$

Big Nana and Pōua raised this large patchwork, mixed-race Kāi Tahu family on a farmlet at Greenhills, a small rural railway siding settlement on the Bluff Road. This was not far from the Native Reserve at Omaui where Pōua had been partially raised. Like their Pākehā neighbours, the family had fruit orchards and vegetable gardens and kept a milking cow. However, they also harvested, preserved and traded eels, whitebait, and a range of other fish and shellfish - identifiably Māori things in identifiably Māori ways. Big Nana also spent periods of time on Ruapuke where Pōua sometimes worked shearing sheep. It was here that Big Nana was taught to weave flax floor mats (whāriki) by Hana Topi (née Parata, formerly Kihau), known as 'Old Ma Topi'. ${ }^{64}$ Pōua and Big Nana's proximity to the aforementioned village (kaik) of Omaui is noteworthy. This was a favoured locale for sourcing rimurapa for pōhā, and also harakeke for weaving baskets (kete). These continued to be important aspects of Big Nana's life in that Pōua also had rights to various Tìtī Islands. She thus visited and harvested tītî from the island Pikomamaku-nui with him and his extended family. In preparation for this, Big Nana would mobilize much of the Greenhills community, predominantly Pākehā people, under the guise of a picnic, to help gather the rimurapa. The need to do this was probably heightened by the sudden death of Pōua who passed away in Invercargill as he was shopping for a present for Tiny's fourth birthday in 1936. 


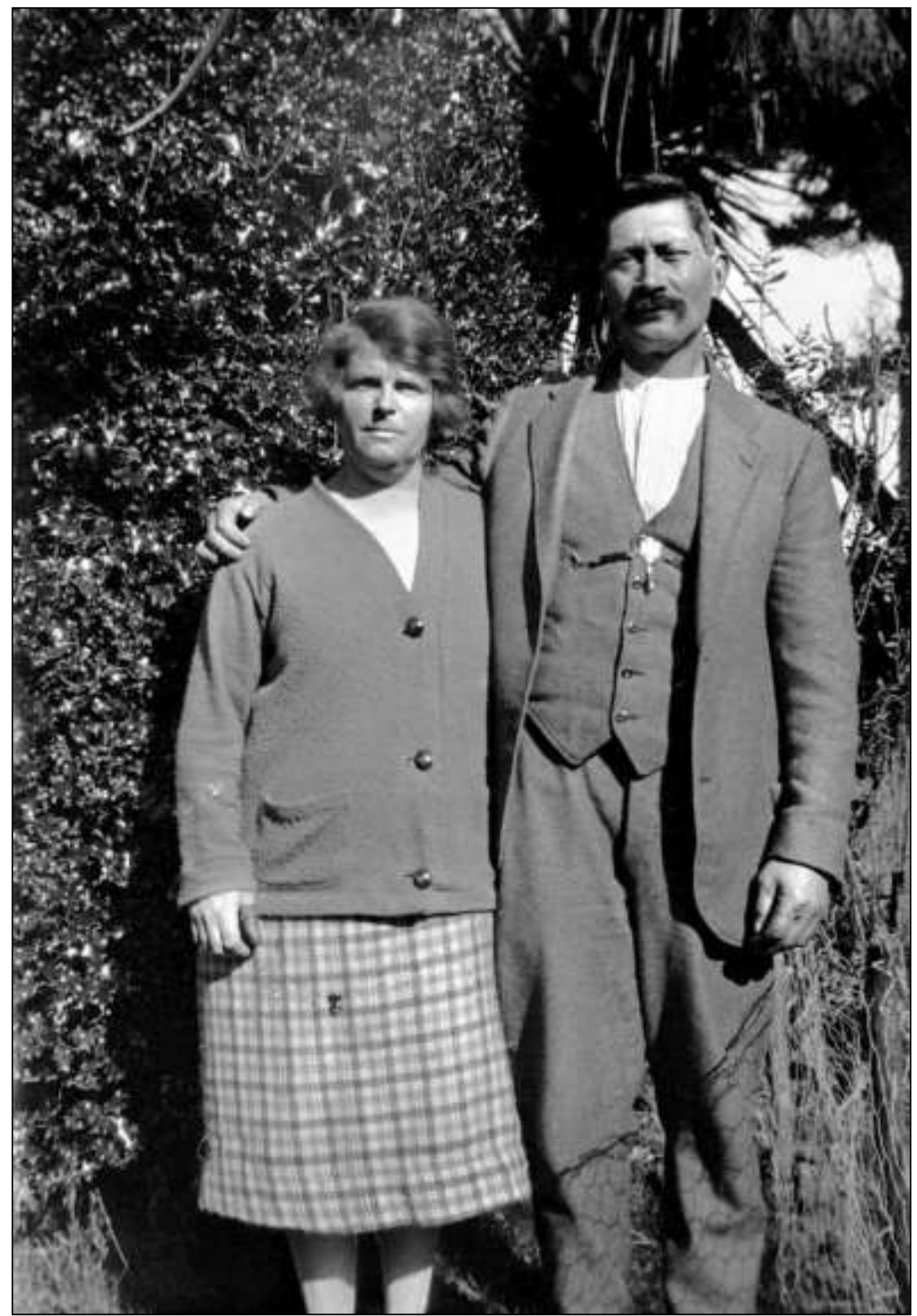

Figure 1: Big Nana and Pōua, Greenhills, c.late-1920s, private collection.

\section{Te Manu Tìtī - Pikomamaku}

As well as being smaller, Pikomamaku is closer to both the mainland South Island and Oban/Halfmoon Bay, Stewart Island's main settlement, than Horomamae. This has both advantages and disadvantages. One of the advantages in Big Nana's time was that her brother Bill, a fisherman, lived at Oban (he still has descendants there). Big Nana and her various charges therefore caught the Bluff-Stewart Island ferry to Oban from where her brother would run them to and from the Tìti Island. ${ }^{65}$ When Bill did not have a boat at his disposal, Big Nana would make alternative arrangements. On at least one such occasion she arranged transport via a Stewart Island based fishing vessel in which one Stan Jones had a shareholding. In return, Jones, an Invercargill accountant who had significant interests in various inshore fishing industries, including Foveaux Strait's famed oysters, was paid a 'passage' muttonbirding speak for an agreed number of processed tìtī, brined or fresh (i.e. nonsalted). He would then sell these through his retail outlets. Much like the first lamb shipped to London in a given year when New Zealand was still 'England's farm', the first muttonbirds on the market in southern New Zealand fetched premium prices. 
With that in mind, Jones wanted a load of fresh birds mid-season. He thus had a boat from Halfmoon Bay bring him out to our island one calm morning.

Unfortunately for Jones, an accountant's morning starts later than a muttonbirder's: the previous day's harvest had already been gutted, salted, and packed into barrels for pickling before he arrived. A hard-nosed businessman who was more feared than loved, Jones was enraged. ${ }^{66}$ From a dinghy lying alongside the island he told Big Nana that he was so wild that if he had a rock he would throw it at her. 'That'd do you no good', she snapped back, 'I'd just pick it up and throw it straight back through the bottom of your boat!' That was the end of that. Big Nana was not just a capable Pākehā in Māori settings; she was a strong woman in a man's world.

Big Nana continued to go muttonbirding for several decades after Pōua died. This was not because she considered it central to her children's, or her own, 'identity' (though it undoubtedly was and remains so). Rather, as Tiny explains:

When Pōua died ... the farm was mortgaged up to the hilt and [Nana] had to bring up the family and pay for everything ... this old guy used to come around and collect the rent all the time, like the mortgage you know ... he would walk all around Greenhills ... getting money off lots of people ... so ... she relied on the island to do that ... whatever you had apart from what you were bartering with, that went in the railway wagon up to town and it went into Todd's, and Todd's used to sell it ... and you got your cheque from there. ${ }^{67}$

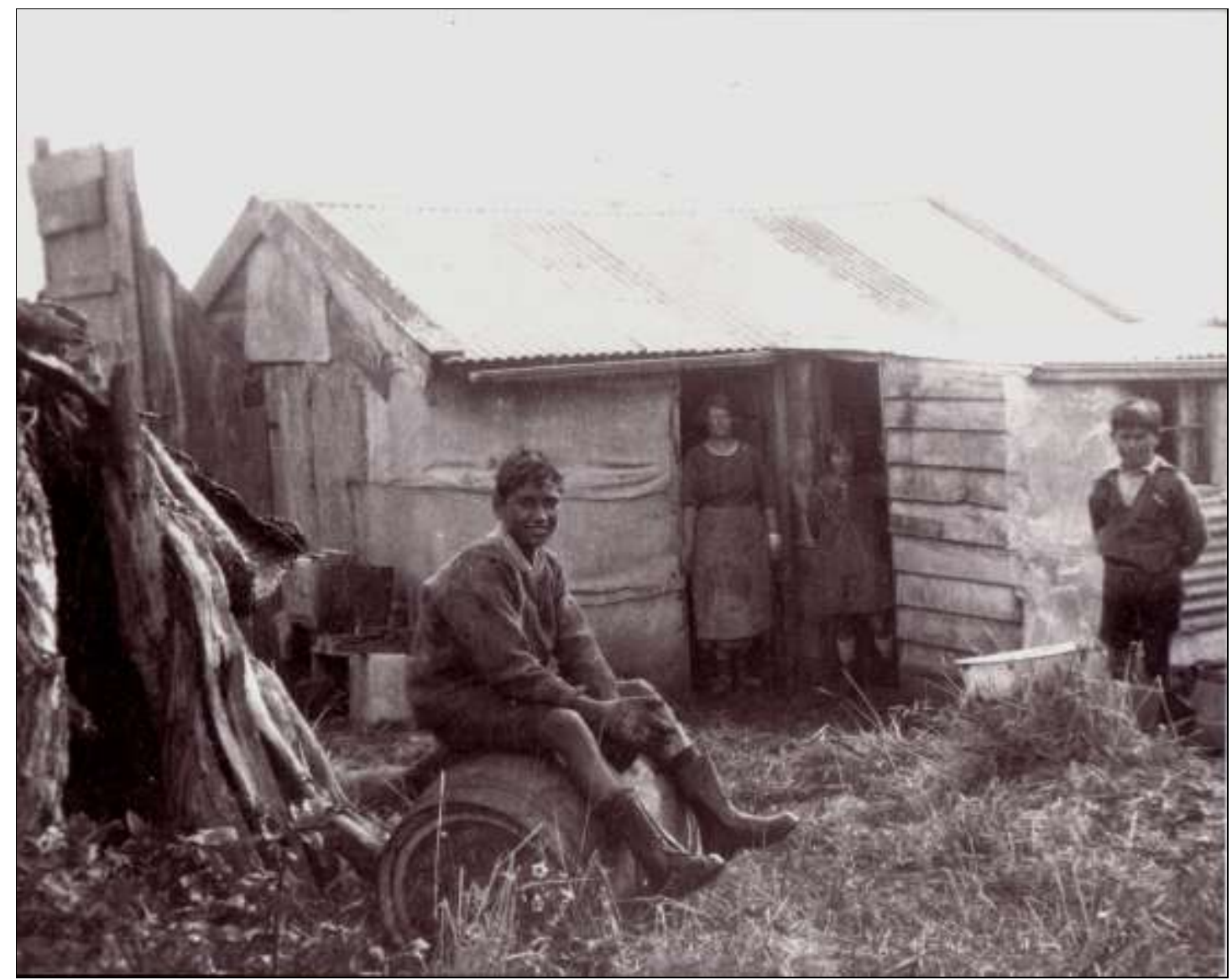

Figure 2: L-R: Buku Hemera, Big Nana, Taura Hemera, and Boy Haberfield, on Pikomamaku-nui, c.1930, private collection. 
By the 1950s the majority of muttonbirders had transitioned from using pōhā to metal tins or wooden barrels in which to hold and transport preserved tîti. These articles were not excluded from Pikomamaku; however they only had a marginal presence. The lion share of the family's catch continued to be preserved in pōhā. Big Nana was the main reason for this state of affairs. She preferred tîti stored in kelp and was attuned to spending time in December and January weaving kete. ${ }^{68}$ The smell and feel of harakeke in her skilled hands was familiar and comforting and she worked it until her worn-out joints no longer allowed. If not when Big Nana ceased muttonbirding in the 1950s, her death in 1966 ultimately gave surviving family members the freedom to cease using pōhā. However, correctly predicting that pōhā-tītî (including the layers of environmental, technical and pedagogical knowledge that underlay this practice) would otherwise become extinct, she had earlier asked one of her eldest mokopuna, and mainstay muttonbirder, my grandfather Tiny, to promise that he and whoever maintained our ahi kā (fires of occupation) on Pikomamaku, would continue to use pōhā. It was not a formal ōhākī (dying speech, parting wish) as such, but Tiny has honoured it with the same level of commitment. ${ }^{69}$

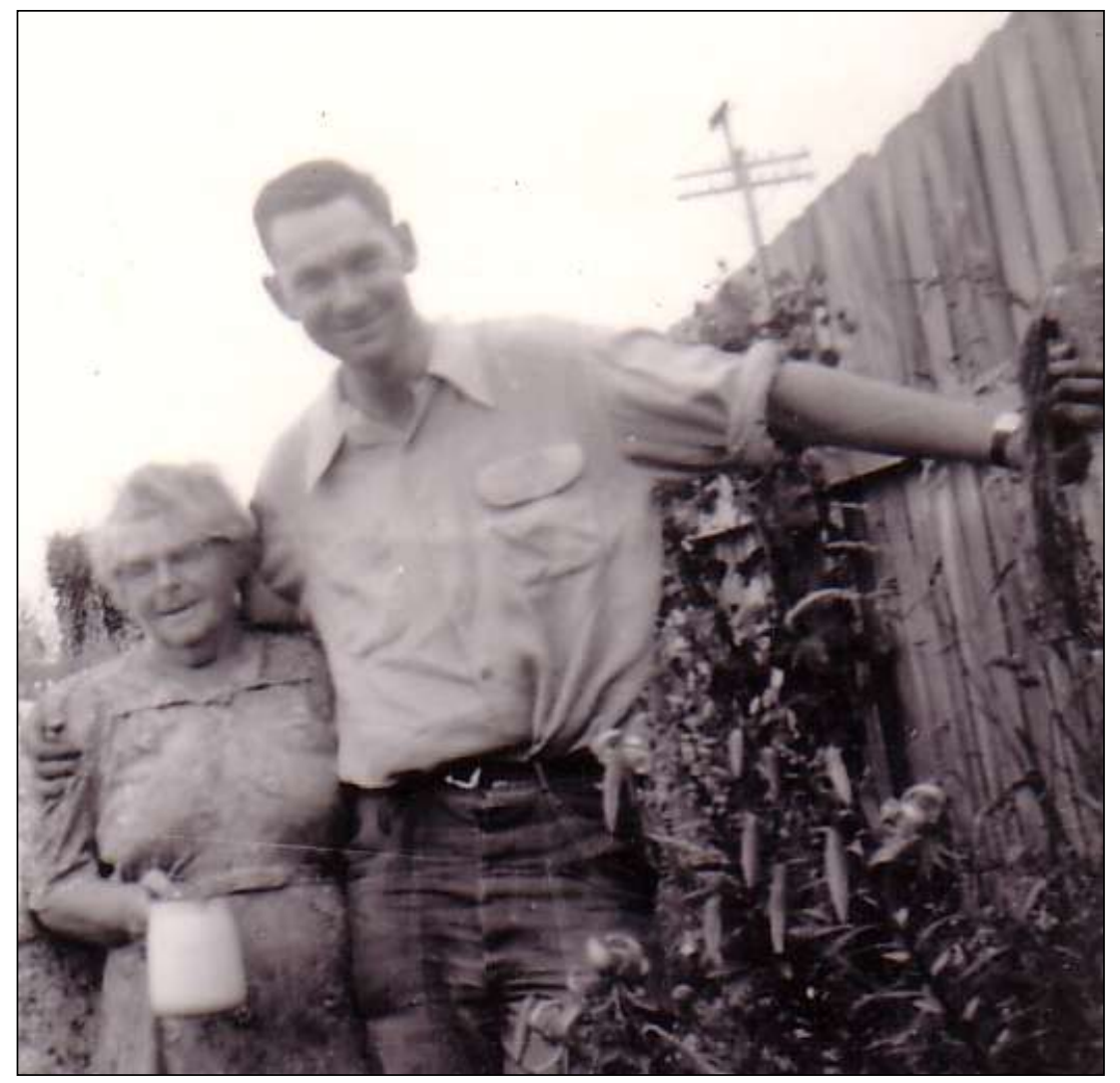

Figure 3: Big Nana and Tiny, c.1960s, private collection.

\section{Conclusion}

In the dining room (whare-kai) at Te Rau Aroha Marae, Bluff - a key institution in Māori cultural revitalization in southern New Zealand over the last 25 years - a feature wall is formed with specially made display pōhā mounted on lattice-work (tukutuku) panels surrounded by stylised representations of tîti. ${ }^{70}$ Although the renowned Māori artist Cliff Whiting (nō Whanau-a-Apanui) oversaw the adornment of the marae complex, it was my blue-eyed and blonde-haired younger cousin Hannah Metzger, with Tiny's guidance, who made the pōhā. ${ }^{71}$ Tiny has also appeared in 
several Kāi Tahu publications in connection with pōhā-tītī and in 2004 was awarded a prestigious Tohu a Tā Kingi Ihaka from Te Waka Toi/Creative NZ, New Zealand's national arts development organization, for his lifelong devotion. In an edition of our tribe's quarterly publication, Te Karaka, the erstwhile editor, referring to pōhā, noted that '[w]e are fortunate that we still have [the Metzger family's] expertise within the tribe'. ${ }^{72}$ What the author and tribal members more widely do not realize, is that we, and they, have a Pākehā woman to thank for this. Kerry Howe criticises the assumption that anyone knows all the wisdom of their world simply because they are 'indigenous'. As he says, '[a]ll knowledge is learned knowledge., 73 The case of Big Nana, therefore, is an attendant reminder that non-indigenous people can become important repositories of indigenous knowledge.

The Kāi Tahu elder statesman Sir Tipene O'Regan once wrote that the 'tool of rigour may be a chisel made of steel, or it may be a chisel made of pounamu - they are handled differently, but they have, properly handled, comparable results' ${ }^{74}$ It does not matter whether the hands that operate pounamu chisels - or construct pōhā - are Māori, Pākehā, or something born of the two. They key point is that the hands are skilled. Big Nana's capable hands, and her pivotal role in the transmission of traditional Māori knowledge, therefore highlight the folly of scholarly approaches that continue to view New Zealand's natives and newcomers as bounded peoples. In Big Nana's own words, let us hope we 'get better as we improve'. 75

I am grateful to Angela Wanhalla and Rani Kerin for encouraging and assisting me to work this essay into its present form. I am also grateful to my grandfather, Tiny Metzger, and whanauka, Lin Mason - two of Big Nana's mokopuna-for reading and commenting on the final draft. He mihi aroha ki a koutou.

1 'Mutton Birds', Otago Witness (Dunedin), 2 July 1902, p.72.

${ }^{2}$ L.E. Richdale, Maori and Mutton-Bird, Dunedin, 1946, p.92.

${ }^{3}$ See Neville Peat, Seabird Genius: The Story of L.E. Richdale, the Royal Albatross and the Yellow-Eyed Penguin, Dunedin, 2011; Richdale, p.92.

${ }^{4}$ Most commonly given as Ngāi Tahu. See www.ngaitahu.iwi.nz and http://www.teara.govt.nz/en/ngai-tahu.

${ }^{5}$ I. Skira, 'Aboriginal people and muttonbirding in Tasmania', in M. Bomford and J. Caughley, eds, Sustainable Use of Wildlife by Aboriginal Peoples and Torres Strait Islanders, Canberra, 1996, pp.167-75.

${ }^{6}$ In 1891 the Crown official Alexander Mackay reported that ' 50 per cent of Ngai

Tahu had no land, and using 50 acres per head as a measure of sufficient land holdings, only 10 per cent ... had sufficient land'. Waitangi Tribunal, Ngai Tahu Report 1991, Wellington, 1991, 2.13. See also Harry C. Evison, The Ngai Tahu Deeds: A Window on New Zealand history, Christchurch, 2006, pp.256-71.

${ }^{7}$ See Michael J. Stevens, 'Kāi Tahu me te Hopu Tìtì ki Rakiura: An Exception to the “Colonial Rule”?', The Journal of Pacific History 41, 3 (2006), pp.273-91.

${ }^{8}$ Cole Harris, Making Native Space: Colonialism, Resistance, and Reserves in British Columbia, Vancouver, 2002, p.xxviii.

${ }^{9}$ See Jacinta Ruru and Michael Stevens, 'Maori land owners and their spouses and partners', New Zealand Law Journal, (October 2007), pp.325-6.

${ }^{10}$ Katherine Ellinghaus, Taking Assimilation to Heart: Marriages of White Women \& Indigenous Men in the United States \& Australia, 1887-1937, Nebraska, 2006, p.xxii. 
${ }^{11}$ They travelled as steerage passengers on the iron square-rigged sailing ship City of Sparta, owned by the City Line of Glasgow. Mervyn McLean, 'Cornish Ancestors \& New Zealand Descendants of Frederick Percy Bailey (1859-1942) \& Elizabeth Cunnack Toman (1858-1928)', unpublished manuscript, Auckland, 2000, pp.27-8. Copy in author's possession.

${ }^{12}$ Ibid., p.32.

${ }^{13}$ It is estimated that between 1840 and 1880 the Māori population declined between 10 and $15 \%$ per decade, before reaching its lowest ebb in 1890, after which it began to recover. John Stenhouse, “"A Disappearing Race Before We Came Here": Doctor Alfred Kingcome Newman, the Dying Maori, and Victorian Scientific Racism', New Zealand Journal of History 30, 2 (1996), pp.135-6. For more information on Pākehā attitudes and responses to Māori depopulation see Raeburn Lange, May the People Live: A History of Mãori Health Development 1900-1920, Auckland, 1999, pp.53-83.

${ }^{14}$ Family tradition suggests that he crewed the famous clipper-ship Cutty Sark that ran on the China tea trade. However, documentary evidence does not support this. What is clear, though, is that Frederick was a seaman. McLean, pp.25-6.

${ }^{15}$ As well as simply growing up in Penzance, the sea was also central in Bessie's life: two of her uncles were master mariners. Ibid., p.26.

${ }^{16}$ From a peak of $£ 56,909$ in 1863 , the value of imports at the port of Riverton declined to $£ 1262$ by 1883 . In 1885 it dropped to $£ 364$ and in 1886 was closed altogether as a Customs and Warehousing Port. Ibid., p.33, fn142.

${ }^{17}$ Invercargill was still connected to its immediate coast at this point in time.

${ }^{18}$ He was more than $£ 110$ in debt meanwhile his only asset, his furniture, was valued at a maximum of $£ 10$. Frederick stated on oath that his wife 'paid him from 30 s to L2 [sic] per month from an income she received from England [via] her father's will (copy of which was produced).' 'In Bankruptcy', Southland Times (Invercargill) (ST), 25 April 1891, p.2.

${ }^{19}$ Georgina Ellis, Time and Tide: Ramblings, Recollections and Reminiscences of the Spencer Family, Invercargill, 2000, p.123.

${ }^{20}$ Ibid., pp.66-72. According to my whanauka, Lin Mason, Louisa's name was not Louisa Te Memeke, but Louisa Adelaide: 'Aunty Bec. told me that Te Memeke was a sort of nickname because of her ability to mimic.' Lin Mason, pers. comm., 13 April 2012. In any event, Louisa and William's eldest daughter and firstborn child was named Louisa Adelaide Spencer. See Ellis, p.73.

${ }^{21}$ Ellis, p.19.

${ }^{22}$ Ibid., pp.66-67, 71-72.

${ }^{23}$ Damon I. Salesa, Racial Crossings: Race, Intermarriage, and the Victorian British Empire, Oxford, 2011, p.25.

${ }^{24}$ Keith Sinclair, 'Why are Race Relations in New Zealand Better than in South Africa, South Australia or South Dakota?' New Zealand Journal of History 5, 2 (1971), pp.121-27; Michael King, The Penguin History of New Zealand, Auckland, 2003, pp.519-20; Salesa, pp.17-18, 22.

${ }^{25}$ By 'crew culture' I am referring to maritime-centred, usually multicultural, lifeways. See Tony Ballantyne, 'Te Anu's Story: A Fragmentary History of Difference and Racialisation in Southern New Zealand', in Alison Holland and Barbara Brookes, eds, Rethinking the Racial Moment: Essays on the Colonial Encounter, Newcastle, 2011, pp.68-9. 
${ }^{26}$ See Michael J. Stevens, "The Ocean is Our Only Highway and Means of Communication": Maritime Culture in Colonial Southern New Zealand', Journal of New Zealand Studies 12 (2011), pp.55-70.

${ }^{27}$ Bill Dacker, Te Mamae me te Aroha - The Pain and the Love: A History of Kai Tahu Whānui in Otago, 1844 - 1994, Dunedin, 1994, p.101.

${ }^{28}$ Ballantyne, p.68.

${ }^{29}$ To which he added, 'but it is not dependent on this'. John Harré, Maori and Pakeha - A Study of Mixed Marriages in New Zealand, London, 1966.

${ }^{30}$ Ellinghaus, p.xii. Ann Laura Stoler, 'Tense and Tender Ties The Politics of Comparison in North American History and (Post) Colonial Studies', in Ann Laura Stoler, ed., Haunted by Empire: Geographies of Intimacy in North American History, Durham, 2006, p.28; Salesa, p.50.

${ }^{31}$ Thomas Betteridge, Shakespearean Fantasy and Politics, Hatfield, 2005, pp.13843.

${ }^{32}$ Ellinghaus, p.xii.

${ }^{33}$ Angela Wanhalla, In/Visible Sight: The Mixed-Descent Families of Southern New Zealand, Wellington, 2009, p.61.

${ }^{34}$ J.F.H. Wohlers, 'On the Dying Out of the Natives of New Zealand', Evangelist or Presbyterian Herald of Otago, 1 August 1870, p.229.

35 'A Noble Digger' further stated that if 'English ladies want colored men for husbands, there is a wide field among the rich and "polished" rajahs and petty princes, and even native merchants of Hindostan'. 'Maori Miscegenation', Grey River Argus, 8 April 1873, p.2.

${ }^{36}$ ST, 3 April 1877, p.3. This article was originally published by the Auckland-based New Zealand Herald, but was reproduced in a number of provincial and local newspapers thereafter. A few weeks later, the Herald noted that its account of this wedding 'was copied into many of the Southern and Australian papers'. 'Marriage in High Life', Evening Post, 14 June 1877, p.2.

37 'Murder at the Chatham Islands', Star (Christchurch), 11 December 1880, p.3. I thank Angela Wanhalla for bringing this incident to my attention.

38 'The Chatham Islands Murder', Star, 12 January 1881, p.3.

39 'The Chatham Island Murder', Nelson Evening Mail, 24 December 1880, p.4.

${ }^{40}$ Bay of Plenty Times, 30 March 1892, p.4.

${ }^{41}$ Kevin J. Mumford cit. Ellinghaus, p.ix.

${ }^{42}$ Salesa argues that New Zealand historians are too quick to equate shared usage of racial and colonial terms with shared understandings of them. Salesa, p.22.

${ }^{43}$ Ibid., p.6.

${ }^{44}$ For example, my step-dad's parents, both Pākehā 'Bluffies', often spoke of their absolute surprise when, quite humorously, they learnt on their Rotorua honeymoon, taken in the late 1940s, that Māori and Pākehā frequented different film cinemas in that town. Similarly, in the mid- to late-twentieth century, Māori looking southern Kāi Tahu were shocked to be variously refused service in some North Island public bars and Wellington taxis, because it was very much at odds with the treatment they received in their lower South Island homelands. Anecdote from Myra Ball's funeral service, St Mary Star of the Sea, Bluff, June 2007; anecdote from tangihanga for Karia (Kay) Pera, Te Rau Aroha Marae, Bluff, 2006; Roger Wyeth (author's fatherin-law), pers. comm., August 2006. See also Harré, pp.126-27; Ellinghaus, p.xi. ${ }^{45}$ Ellinghaus, p.xi. 
${ }^{46}$ Beattie added, 'The collector also saw an English girl of good type, the bride of a tall, handsome Maori soldier'. Herries Beattie, Traditional Lifeways of the Southern Māori, edited by Atholl Anderson, Dunedin, 1994, p.465.

${ }^{47}$ Ibid., p. 24.

${ }^{48}$ Ellis, p. 123.

${ }^{49}$ Ibid.

${ }^{50}$ Stevens, 'The Ocean is Our Only Highway', pp.158-59.

${ }^{51}$ Ibid., p.165. As Beattie wrote in 1944, 'There are probably more residents with Maori blood in Bluff than in any other town in the South Island'. Quote is in Ibid.

${ }^{52}$ Referring to one of George's nephews, Alfred (Alfie) Tumaiteuru Ryan (19121993), it is said that 'even the Pakeha kids called him Poua'. Ellis, p.101.

${ }^{53}$ Herries Beattie, Our Southernmost Maoris, Dunedin, 1954, p.8.

${ }^{54}$ Harré, p. 144.

55 Tiny Metzger, interview with Michael Stevens, April 2003.

${ }^{56}$ Ellis, p.70.

${ }^{57}$ Ibid., p.123. Several of Big Nana's children, grandchildren, great-grandchildren and great-great-grandchildren are also left-handed, myself included.

${ }_{58}$ Beattie, Lifeways, p.177.

${ }^{59}$ Ellis, pp.70, 160.

${ }^{60}$ Ibid., p. 124.

${ }^{61}$ See Michael J. Stevens, 'Kāi Tahu Literacy and Cross-Cultural Communication', Journal of New Zealand Literature 28, 2 (2011), pp.130-57.

${ }^{62}$ Uncle Carl went on to marry Big Nana's sister, Ivy (1898-1991).

${ }^{63}$ See Stevens, 'The ocean is our only highway', p.160.

${ }^{64}$ Hana's sister, Hera (Taua Sal) Ellison (née Parata, formerly Harper), is my wife's great-grandmother. Hana's second husband was descended from Teone Topi Patuki, who was first cousins with Teitei, Pōua's paternal grandmother.

${ }^{65}$ The ferry at this time was the Tamatea, which was privately owned by its master, Captain Hamilton. The New Zealand government later commandeered the ship during the Second World War. After the war, the government owned Wairua, and from 1961 the Wairua II, provided the Bluff-Stewart Island freight and ferry service. The latter was disposed of in 1986 by New Zealand's Fourth Labour government (1984-1990) as part of its across the board programme of state asset sales and neoliberal economic reform.

${ }^{66}$ That said, Tiny, who later worked for Jones as a boat-builder, recalls that 'he was the only boss who ever asked me if I wanted a raise'. Metzger, interview.

${ }^{67}$ William Todd \& Co. Auctioneers, an iconic forth generation family business based in Invercargill's Rialto Auction Rooms from 1865 until June 2011. Dan Hutchinson, 'William Todd and Co auction building closing', ST, 23 March 2011; Metzger, interview.

${ }^{68}$ Ellis's abiding memory of Big Nana's house in Bluff, which she retired to from Greenhills, was 'the distinctive aroma of flax and kelp. A bag of titi usually hung from a coat peg beside the old wringer washing machine.' Ellis, p.125.

${ }^{69}$ Rob Tipa, 'Preserving a family tradition', Te Karaka 51 (Kana/Spring 2011), p.32.

${ }^{70}$ Reminiscent of Big Nana weaving whāriki, the tukutuku panels in question were woven by our Pākehā grandmother, Maurine Metzger, and Heather Whiting, also a Pākehā originally from Invercargill. 
${ }^{71}$ Hannah was then approximately 12 years old. Tiny recalls that she wrote her name and the date on the rear of the panels.

${ }^{72}$ Gabrielle Huria, 'Editorial', Te Karaka 14 (Makariri/Winter 2000), p.1.

${ }^{73}$ K. R. Howe, Nature, Culture, and History: The "Knowing”" of Oceania, Honolulu, 2000, pp.82-83.

${ }^{74}$ Pounamu, or nephrite jade, is the veritable tungsten steel of the pre-European Māori world. See Rusell Beck with Maika Mason, The Jade of New Zealand: Pounamu, Auckland, 2010; Tipene O’Regan, 'Old Myths and New Politics: Some Contemporary Uses of Traditional History', in Judith Binney, ed., The Shaping of History: Essays from the New Zealand Journal of History, Wellington, 2001, p.35. ${ }^{75}$ Commenting on Tiny's progress at plucking tîtī when he was a child, Big Nana used to remark that he 'is getting better as he improves'. 